\title{
The Progressive Development of Multifunctional Composite Materials in Different Applications
}

\author{
Muhammad Akhsin Muflikhun \\ Department of Mechanical and Industrial Engineering, Faculty of Engineering, Gadjah Mada University \\ Email: akhsin.muflikhun@ugm.ac.id
}

Received: June 1, 2020; Accepted June 19, 2020; Published : November 1, 2020

\begin{abstract}
Composite materials gain huge interest from researchers due to its advantages and flexibility. Strength and properties that can be adjusted based on the needs and application is a specific advantage of composite materials. Since these advantages can be applied in many fields, composite materials often clustered in multifunctional materials. This study aims to lists and classified the progressive development of multifunctional composite materials that found and already proven can be applied in many applications. This study also gives data that can be driven to readers from different backgrounds and used it for further purposes. The results are shown that the progressive development of multifunctional composite materials not only one step forward in the technical achievements but also the energy and environment-related to human ecosystems.
\end{abstract}

Keywords: Multifunctional materials; Composite; Coating; Nanomaterials

\begin{abstract}
ABSTRAK
Material komposit memperoleh minat yang besar dari para peneliti karena kelebihan dan fleksibilitasnya. Kekuatan dan sifat yang dapat disesuaikan berdasarkan kebutuhan dan aplikasi adalah keuntungan spesifik dari bahan komposit. Karena keuntungan ini dapat diterapkan di banyak bidang, bahan komposit sering dikelompokkan dalam bahan multifungsi. Kajian ini bertujuan untuk mencantumkan dan mengklasifikasikan perkembangan progresif bahan komposit multifungsi yang ditemukan dan sudah terbukti dapat diaplikasikan dalam banyak aplikasi. Studi ini juga memberikan data yang dapat mendorong pembaca dari latar belakang yang berbeda dan menggunakannya untuk tujuan lebih lanjut. Hasilnya menunjukkan bahwa perkembangan progresif bahan komposit multifungsi tidak hanya satu langkah maju dalam pencapaian teknis, tetapi juga energi dan lingkungan yang berhubungan dengan ekosistem manusia.
\end{abstract}

Kata Kunci: Material multi-fungsi; komposit; Coating; Nanomaterial

\section{INTRODUCTION}

One of the many advantages of composite materials is about flexibility. It can be engineered, modified, and designed to give more than one enhanced mechanical and physical properties. The outcome of this research often we can call multifunctional composite materials (MCM). Beside have similar performance to traditional composite laminated that have high specific strength and stiffness with minimum weight, MCM has advantages in one or more points compared to the traditional composite structures. For example, by adding carbon nanotubes (CNTs) into its matrix composites, the electrical conductivity becomes much higher compared to the traditional composite laminates. Moreover, in many studies, MCM can enhance more than one property that can give added value when compared to other systems, such as self-healing system, antimicrobial effects, sensing technology, and automotive structures [1-4].

The self-healing mechanism by using composite material has been reported by Guadagdo et al. [5]. By using reversible hydrogen bonds generated by a combination of epoxy resin and polyhedral oligomeric silsesquioxane (POSS) nanocages. These compounds then employed to activate the self-healing mechanism by using heat. In resin composition, multiwalled carbon nanotubes (MWCNT) were mixed to enhance the healing efficiency of up to $400 \%$. Moreover, this mechanism also reported can reduce fatigue crack growth rate of composite laminates that contain multifunctional formulations.

In aerospace technology, a new novel epoxy resin was introduced by Arena et al. [6] that can be applied in aerospace applications. The epoxy was mixed with rubber-based materials. To increase the performance of the composite, Carbon nanotubes (CNTs) also embedded into the system to make the layers suitable for extreme conditions. The CNTs blended with epoxy also increase its electrical properties and make it electrically conductive. This electrical property can be used in wider applications such as self-health monitoring during static and dynamic loads $[7,8]$.

This study purposes to analyze multifunctional composite materials from selected resources of a 
reputable journal. This study includes both three major clusters of multifunctional composite materials which are carbon fiber composites, hybrid composites, and green composites. For the combinational section, this study is the first time that makes listed and comparison of 3 different composites. As the author's understanding view, there is still a limited source of a study and research paper that did the same as the present study, compared to the previous studied that done by the researcher. The work was performed as a review with a compact analysis from the previous work with important summarized was done about the development of multifunctional composite materials. The paper also described the manufacturing process and the results of the multifunctional composite materials with the recent progress on three different clusters of multifunctional composite materials that mainly developed on a laboratory scale.

\section{METHODS}

The methods of this study are obtained with the aim to identify the current condition of the academic resources with regards to multifunctional composite materials. For data availability, a research topic that focused on the multifunctional composites, and sustainable materials used in composites applications, the searching is done in 3 different databases which are ScienceDirect, Scopus, and Google Scholar. The literature reviewed in the present study were used selected papers using three steps: (1) searching the selected literature by setting the searching the words that have same criteria in the database to identifying the targeted paper; (2) extracting the important information that showed in the selected paper by reading systematically from the 3 sections, introduction and conclusion; (3) In the top important papers, the author read thoughtfully all entire papers.

\section{RESULTS}

The results of the current screening of the papers are listed and categorized into three sections which are Carbon fiber composite, Hybrid composite, and Green composite. All three sections can be classified into multifunctional materials that can be implemented in different applications.

\subsection{Carbon Fiber Composites}

Carbon fiber composites (CFC) are usually used in aerospace industries as the main structures at the latest manufacturing process. In the recent development, the applications of CFC are not exclusively in the aerospace fields but also included in different applications such as automotive, buildings and bridges, blades, and different sectors. The advantages of the CFC that lightweight, high strength to weight ratio, corrosion resistance, easy to assembly and can be used in wider temperatures were the reason why CFC is used although the price is still high [9-13]. The following description of the selected CFC papers is shown and described.

Forintos and Czigany [7] studied and summarized the multifunctional application of CFRP in different applications based on its electrical properties. It was reported can be applied in crosslinking, welding, sensors based CFRP, self-healing, energy, transportation, and industry 4.0. the summarized also included different fiber such as glass fiber. To increase its electrical properties, conductive nanomaterials (multi-walled carbon nanotube, carbon black) were inserted and mixed with epoxy resin and then impregnated into the fiber.

Carbon fiber mixed with graphene nanoplatelet/manganese oxide electrodes that can be applied as supercapacitor in CFRP multifactional materials was studied and reported by Masouras et al. [14]. Graphene nanoplates were modified using $\mathrm{MnO} 2$ with the sonication method in an organic solvent. The composites material was prepared for energy storage ability by a combined solution on an aluminum substrate and wet carbon fiber (CF). The morphology of the graphene composites was characterized by using SEM. Furthermore, differential scanning calorimetry (DSC) was used to characterize the thermal stability of the electrolytes. From the DSC output, the promising composites material is confirmed and show stable condition from the range $-40{ }^{\circ} \mathrm{C}$ to $140{ }^{\circ} \mathrm{C}$. this result claimed can be applied in various sectors such as automotive, aerospace, and wearable electronics. To increase the mechanical properties of the composites, epoxy was inserted using a weight ratio 1:3. The results show that stiffness increased from 11 to $23 \mathrm{GPa}$ and the strength increase from 87 to $173 \mathrm{MPa}$.

\subsection{Hybrid Composites}

A combination of 2 or more conventional material often can create a system or material that has good properties from each part. A combination of 2 materials does not make one or the new combination can 
be weaker. Hybrid materials can be used as an intermediate combination of materials that compromised between price and performance. With an affordable budget, the performance of hybrid material can be beyond the single material. Hybrid materials also already proven can be applied in many fields including marine applications, electrical components, environmental, catalytic, biological, automotive, space shuttles, and energy conversion to energy storage $[8,15-17]$.
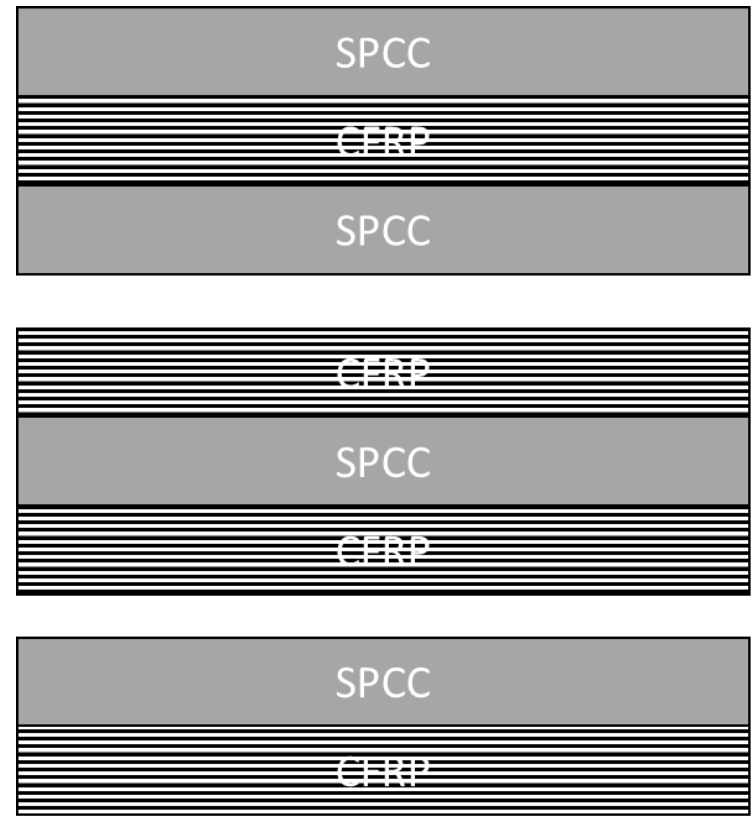

Figure 1. Combination of CFRP and SPCC (A) double SPCC layers, (B) double CFRP layers, and (C) single CFRP and SPCC layer.

The studies conducted by Muflikhun et al. [2,18] shows that CFRP combined with steel plate cold commercial (SPCC) is suitable for use in automotive and building structures. The mechanical properties of hybrid laminates show beyond the expectation when the CFRP or SPCC used as a single material. The simple preparation, manufacturing process, and easy to be applied in direct structural parts are the main advantages of its application. There are 3 different combinations of CFRP and SPCC that have been evaluated as shown in Figure. 1. Since the highest strength occurred in the CFRP laminates with the direction of the fiber is longitudinal with fiber orientation, the failure behavior of the fiber also related to the angle of the fiber. Moreover, adding more SPCC layers can increase the initial stiffness but lower the stiffness in the plastic region. Hence in Figure. 1 (A), the stiffness is lower compared to Figure. 1 (B) and Figure. 1 (C) when it is assumed that all CFRP layer is in the longitudinal direction to the loading direction. In the multi-angle and combinational pattern of the CFRP layer, the stiffness and strength of the laminates can be adjusted. This condition also became the added value of the hybrid composite compared to metallic materials.

Besides carbon or glass fiber, the research about multifunctional materials also reached natural components such as wood that combined with resins for different applications. Barletta et al. [19] used protective layers by dipped it inside a fluidized bed (FB) of wood ad polyphthalamide powders on the aluminum substrate. The results show that micromechanical and tribological of the coating layers were significantly improved due to the effect of wooden particles. The additional thermal insulation was achieved with good adhesion and wear performance. The coating process used the hot-dipping technique implemented in a fluidized bed of dry materials and followed by wet dipping inside the resin. the study proposed 4 different types of coating (A, B, C, and D) and reference. The results of the different coating processes are shown in Figure. 2. Although there is no relevant damage or macrocracks appeared, the results show that coating $\mathrm{A}$ and $\mathrm{C}$ have less responsive in constant load by scratch test. This condition happened due to the lack of an intermediate acrylic layer collated between underlying wooden and topcoat. For type B and D, the results show that the scratch is more accurate and exhibits a stiffer long distance. Moreover, coating B and D show excellent wear response. This confirmed from the wood-reinforced resin that visually detected (came out). 


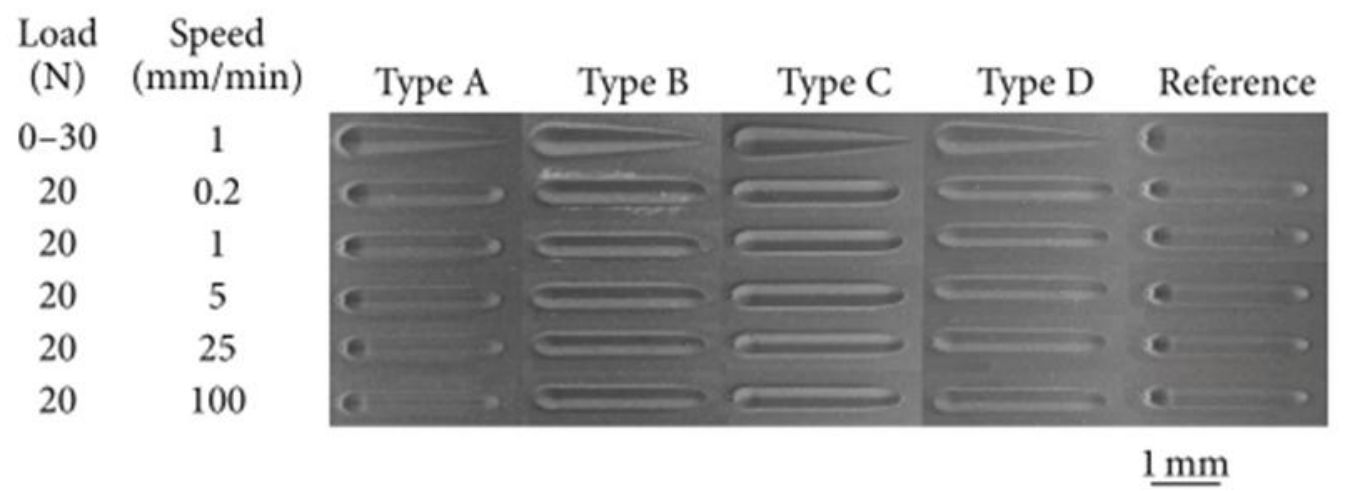

Figure 2. Residual pattern images captured from SEM [19].

Zhou et al. [20] studied clay that can be applied in multifunctional membrane technology with nanostructured. In their study, natural clay minerals can be exfoliated into nanosheets with designed properties. On a macroscopic scale, the size can be controllable and on a microscopic scale, its structures can be arranged. The work itself used three approaches of exfoliation and compared six steps assembly which is casting, coating (dip and spray), vacuum filtration, electrophoretic deposition, and 3D printing. The study shows that natural clay after manufactured into functional membrane can be applied in chemistry [21], biology [22], energy [23], and environmental issues [23]. The advantages and disadvantages of using the different processes are summarized in Figure. 3, where the data are mined from Zhou et al. [20].

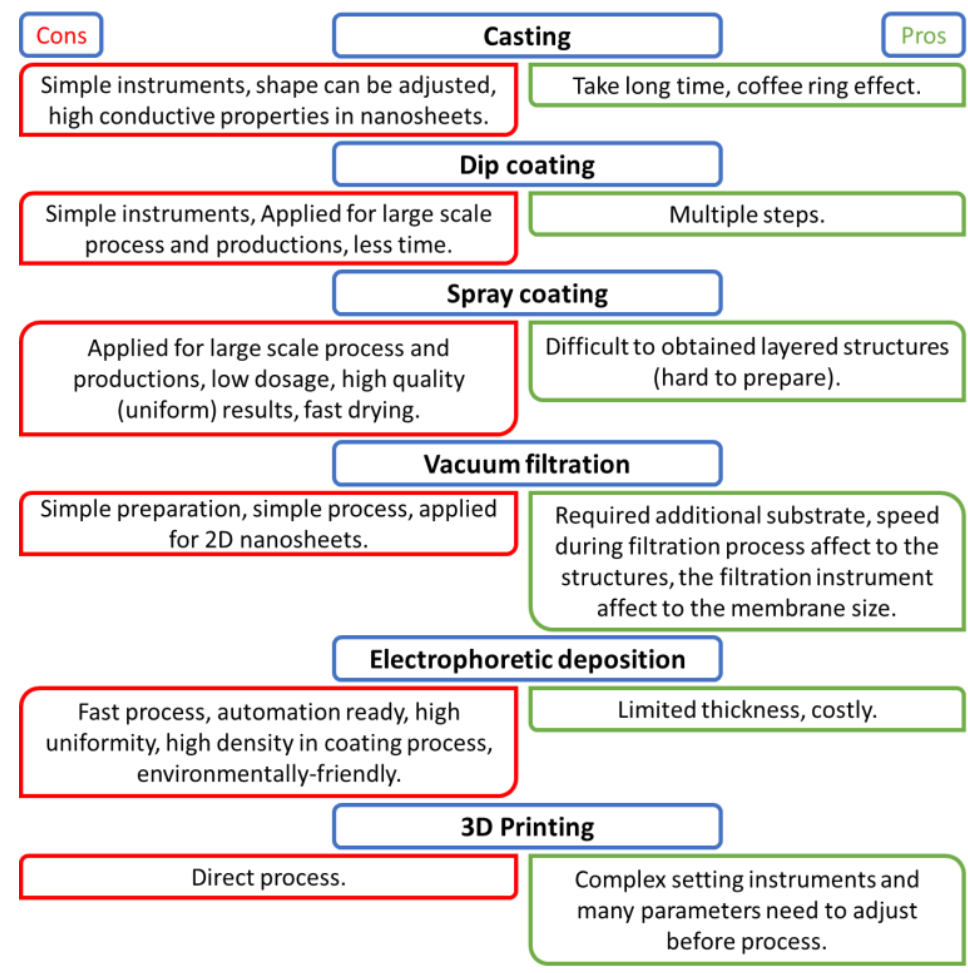

Figure 3. Comparison of manufacturing of clay nanomaterials using different methods.

\subsection{Green Composites}

In the last couple of decades, scientists have aware of the effect of climate change because of pollution and environmental destruction because of human activity. One of the effects of high air pollution and climate change is the rise of global temperature. This condition makes human life became less comfortable. To against and to reduce global pollution, researchers make a material that has less pollution and uses natural products in many applications. The composite that used environmentally friendly material is called green composite [24-29].

The environmentally friendly manufacturing process of composites was informed by Iqbal et al. 
[30]that the product can be used as a catalyst in various applications. Laccase assisted grafting were manufactured with the source material of laccase are obtained from Aspergillus niger that combined with Saccharomyces cerevisiae as a green catalyst. The product, poly(3-hydroxybutyrate) $[\mathrm{P}(3 \mathrm{HB})]$ grafted ethyl cellulose (EC) then characterized using the imagining method, FTIR, and X-ray diffraction (XRD). The study claimed that the improvement in thermal and mechanical was achieved with the hydrophobic and hydrophilic properties of the study is far better compared to the other similar products. the study also mentioned the advantages of the present product compared with the other, such as eco-friendly process, easy to prepare, less energy used, high added-value, excellent in tensile strength, good mechanical strength, and less harsh chemical.

Sheikh and Teli [31] used bamboo combined with $\mathrm{ZnO}$ nanoparticles in textile materials. The bamboo- $\mathrm{ZnO}$ composites were manufactured by swollen grafted fabric with $\mathrm{ZnCl}_{2}$. After it was prepared, then the composite materials were characterized and evaluated for antibacterial purposes using gram-positive and gram-negative bacteria. The results show excellent potential for antibacterial applications where the eradicating process was found until 40 times of washes. This product also showed good protection against UV and was suitable for multifunctional textile material. As a unique, the study immobilized $\mathrm{ZnO}$ nanomaterials on acrylic acid grafted bamboo rayon (AA-g-BR) with the further analyzed the efficacy of modified fabrics.
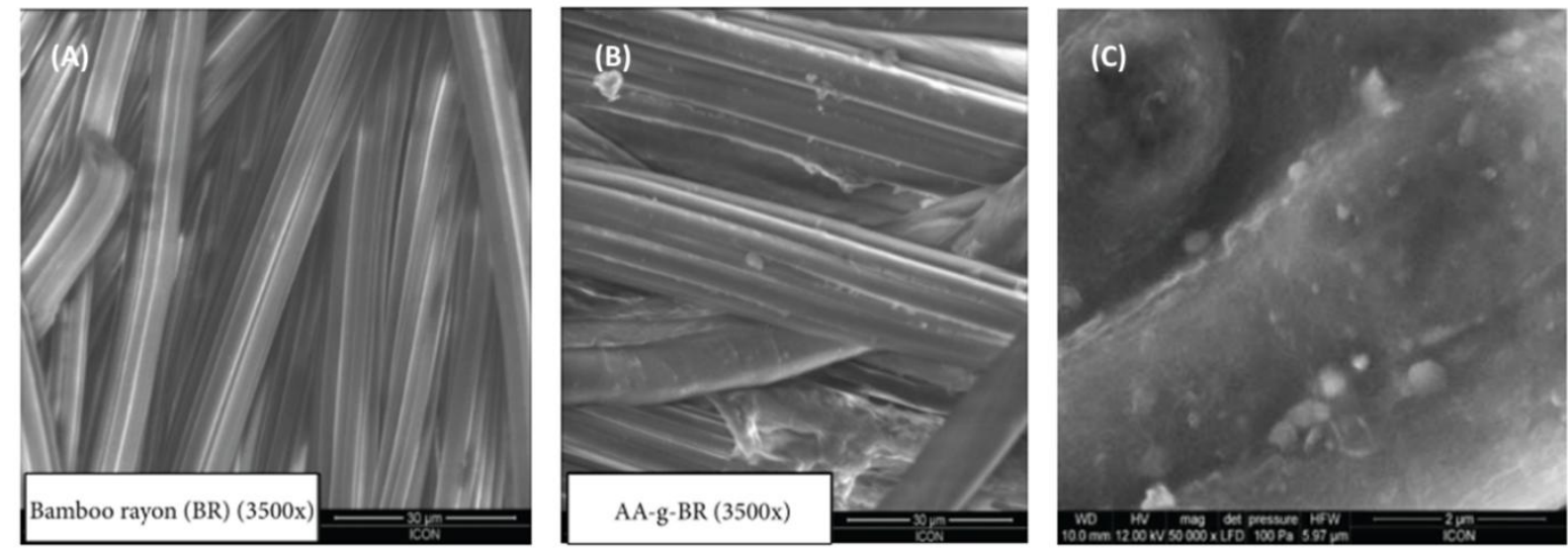

Figure 4. Images captured from SEM of (a) bamboo rayon, (b) AA-g-BR, and (c) nano ZnO-AA-g-BR. [31]

In Figure. 4 there is evidence of the presence of $\mathrm{ZnO}$ nanoparticles in Figure. 4 (c) compared to the Figure. 4 (a) or (b). the $\mathrm{ZnO}$ nanoparticles are visible by dots-like that adhered to the surface of modified bamboo rayon where the agglomeration of $\mathrm{ZnO}$ nanoparticles also clearly observed. Furthermore, the antibacterial performance of the bamboo composites is shown in Figure. 5 and Figure. 6, where the data are mined from [31].

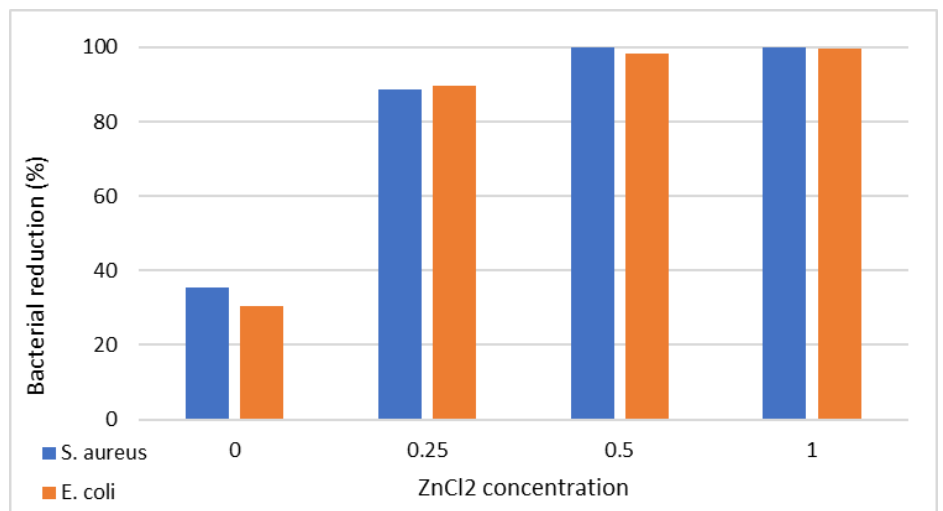

Figure 5. Different $\mathrm{ZnCl}_{2}$ concentration in its antibacterial properties of nano $\mathrm{ZnO}-\mathrm{AA}-\mathrm{g}-\mathrm{BR}$.

The comparison is based on the difference of $\mathrm{ZnCl}_{2}$ concentration and the number of washes. The concentration shows that the efficiency reached when the ratio of $\mathrm{ZnCl}_{2}$ 0.5. the bacterial reduction slightly decreased in E. coli. For the endurance of the material related to the number of washing, the decreasing 
percentages reached $40 \%$ after 50 times of washes. This condition shows that the reduction is reached up to $80 \%$ and still have nlmore than $50 \%$ efficiency. The decreasing factor that occurred due to the thinning effect of nanoparticles after intensive washes.

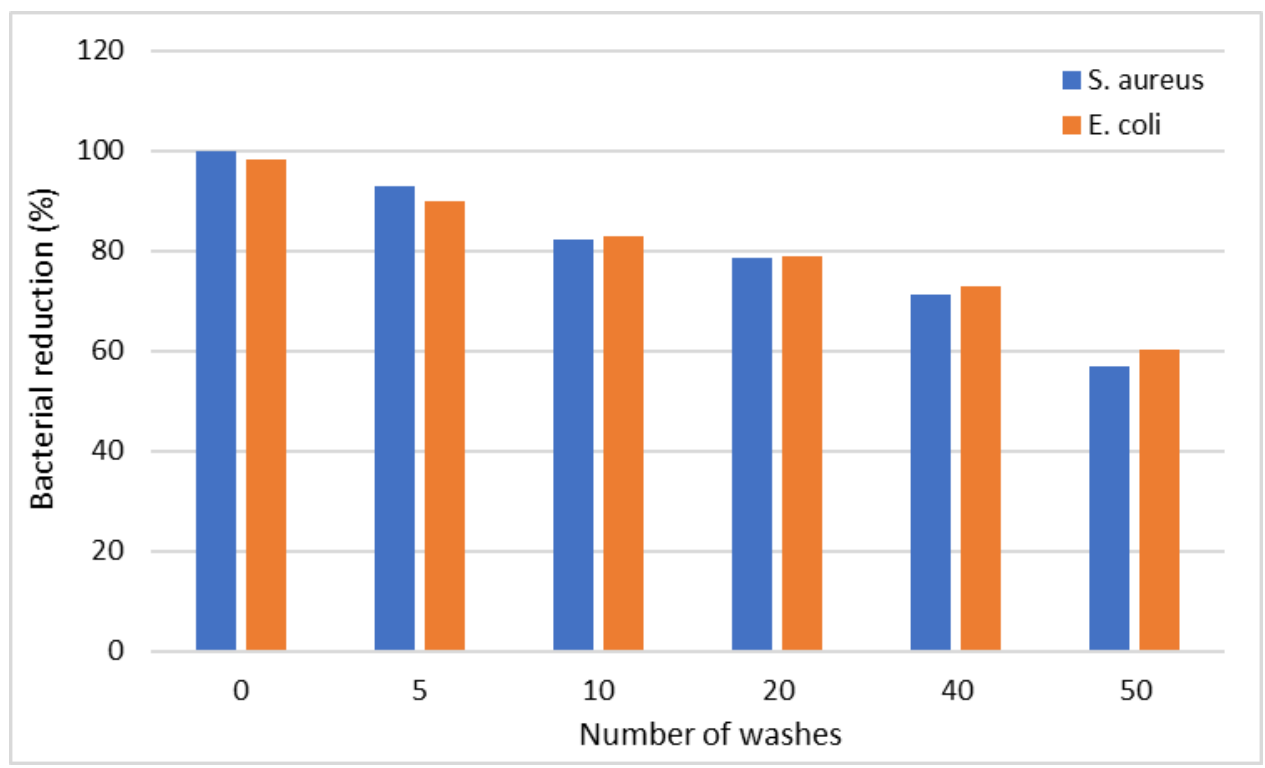

Figure. 6 Antibacterial performance of grafted sample (Zno 0.5\%).

\section{DISCUSSION}

The general state in the composite world mentioned that multifunctional composites are placed in the top priority for engineers and designers to used it. Multifunctional composite is cheaper and simple to be applied in different situations and conditions [1,32,33]. The present study collected several papers and selected books related to the multifunctional materials relevant to the present situation. 3 main topics present in this paper, multifunctional material in carbon fiber (CF) composites, hybrid composites, and green composites. CF composites are an important material used specifically in the aerospace industries. Parts and structures of airplanes used CF composite because of its advantages in mass compensations over metallic materials, strength, corrosion resistance, and higher specific mechanical properties [34].

In hybrid composites, several testing has been done by many researchers to evaluate hybrid performance using different testing procedures such as Axial test, Flexural test, and ENF test [35,36]. Hybrid laminates are a unique combination of two or more material, used in many aspects with the benefits from its parts. Also, by adding nanocomposite into its structures, the higher mechanical properties are achieved with the addition of its applications such as for mechanical reinforcement, drug delivery, bioactivation, tissue engineering, and energy storage [8].

Green composites became a hot prospect due to its natural source and recyclable process. Since the structure of the materials is gathered from nature, the source material is relatively easier to collect. To reduce pollution as an example, a new green packaging material is developed by many researchers using bio-based matrices, bio-based nanofillers, and cellulose. Moreover, researchers also developed green foams, bio-based resin, biopolymers for drug delivery, starch-based bio-composites, and wood-based adhesive [25].

Intensive research of multifunctional composite materials occurred for a couple of decades. Furthermore, the development of composite materials was done since the medieval era and was determined by alchemist and scientist that used their knowledge to make colored glass used in religious places [37]. Since that, multifunctional composites and structures are used for different purposes and many applications. Carbon fiber composites are well known as the "miracle" material that changed technology and structures of airplanes. In the recent typed of aircraft, more composite materials are used ( $>25 \%$ in Airbus 380 , and $>50 \%$ in Boeing 787) [38]. A study \%about Boeing 787 fuel efficiency shows that by reducing $20 \%$ of total weight, resulted in $10 \%$ to $12 \%$ fuel can be saved [39]. Although the advantages of carbon fiber composites show the huge potential applications in the futures, recent conditions show that the high price of it still became a factor barrier that carbon composite has limited applications. Another factor to be considered is the recycled process 
and environmental issue related to carbon fiber composites [40,41].

Since carbon fiber composites have a limitation, researchers tend to make a solution by combining carbon fiber composite with existing material (hybrid laminates) such as metal or natural-based material to reduce the cost and easy to recycle. The hybrid laminates have several advantages; cost saving with the performance beyond metal-based or natural-based materials, recyclable, failure predictable, max. strain beyond the carbon fiber composite, and easy to manufacture [35,36,42]. Although hybrid laminates have several advantages, strength, weight ratio, and market availability still became a challenge to hybrid laminates $[43,44]$.

On the other side, the applications of multifunctional composite materials also attract the attention of experts and researchers in terms of sustainability and environmental issue. Many papers published show how to recycle carbon fiber and hybrid materials using different methods. The complexity and multi-step recycling processes create a high cost and spent more time [45-47]. To reduce the domino effect of these processes, scientists try to make a multifunctional composite material based on green technology and used green materials (natural-based materials). Natural fibers have less competitive points compared to carbon fiber such as low mechanical strength, low thermal stability, and high degradation [48]. However, natural fiber still became a better choice due to its flexibility, easy to manufacture, and machinable [49], stable and available to combine with other materials and fibers [50,51], have a better life cycle assessment [52], and low-cost recycling process [53].

For instance, the comparison factor between carbon fiber composites, hybrid composites, and natural-based composites can be seen in Figure. 7. The 7 aspects are used to compare the three different types of fiber composites. The most prominent aspect scored with 3 and the less prominent scored 1 . It is shown that in term of strength, carbon fiber is the best choice but have less competitive for cost and recycling process. Hybrid composites show the average aspect that became bridge materials that can be used by researchers, designers, and engineers if they have to deal with the cost without compromising performance. For natural fiber composites, plenty of resources from nature became beneficial factors with high recycling factors and flexibility.

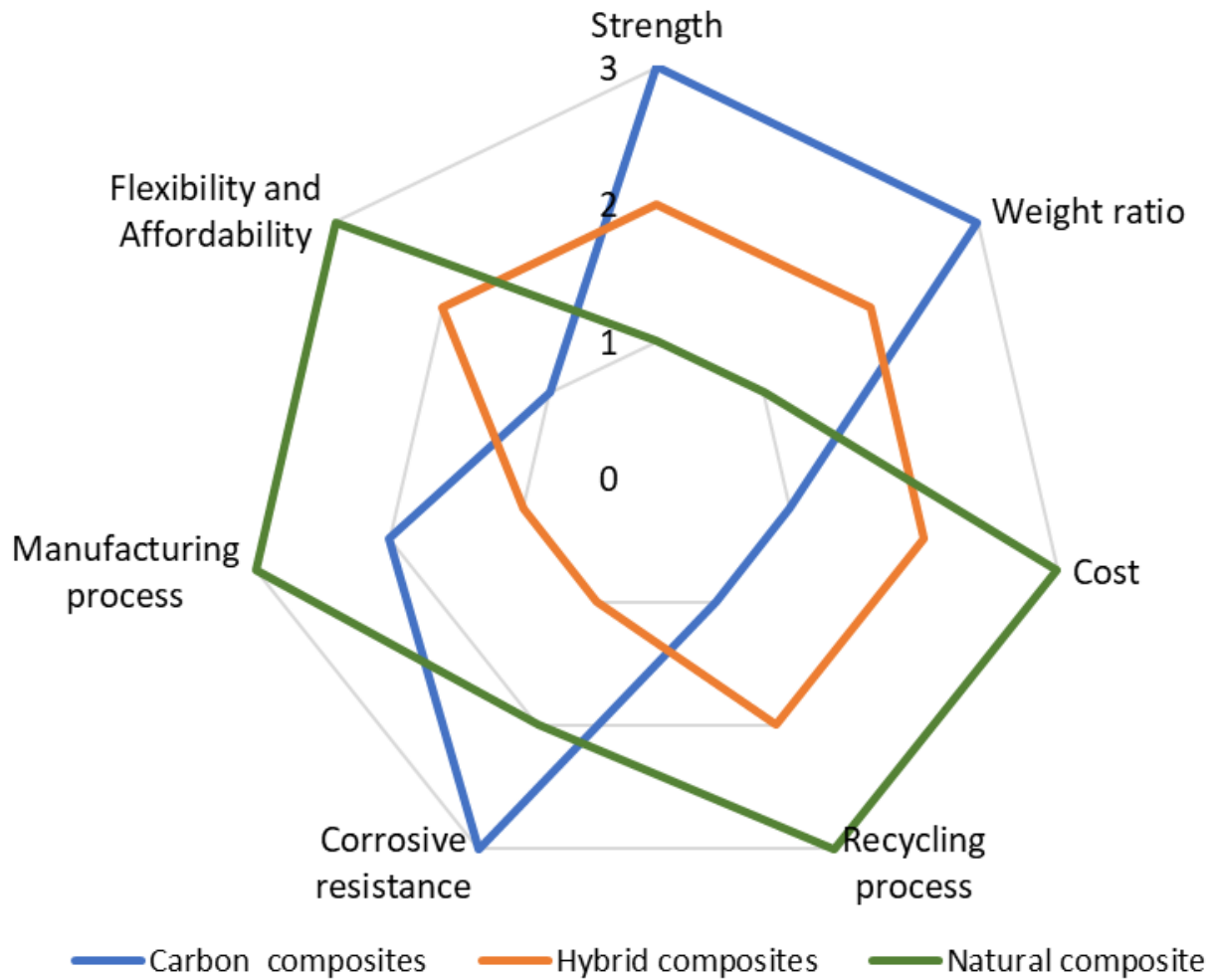

Figure 7. Comparison of carbon fiber composites, hybrid composites, and natural fiber composites in different aspects. 


\section{CONCLUSION}

The present paper shows that many signs of progress have been made in multifunctional material that fabricated and manufactured from different methods and techniques. Each technique has its uniqueness and has specific purposes. Besides the conventional technique, there is also a progressive technique based on a green technique and has characteristics with less harm to the environment (environmentally friendly). The progressive development of the multifunctional materials gained interest by many researchers due to the needs of the materials that can be applied in many aspects. Not only in a specific aspect. The advantages of multifunctional material are about flexibility. Where the application is a wider and only used single product, the cost, time, energy, and resource materials can be minimized. Make multifunctional material is potential and compulsory in the near future. At now a day, the applications are already covered in aerospace, automotive, chemical, biological, and physical applications, energy development and harvest, transportation sectors, educational and research tools, buildings and structures, and many more. Besides, it is interesting to observe that a material that previously only looked and used in a single purpose, can be enlarged and adjusted to use in different applications, and still give its strong performance. By adding simple modifications, the multifunctional materials also can reach their limits and give a huge added value to the different applications.

\section{Acknowledgment}

The author would like to say gratitude to Mubarokah, Aflacha, Habli, Fadhilatun, Alviana, and Nikmatul for their support and spent time with the author during the WFH activity due to Covid-19 pandemic. The author also wants to express his gratitude to Mechanical and Industrial Engineering Department, Gadjah Mada University for the funding project.

\section{REFERENCES}

[1] E. J. Barbero, Ed., Multifunctional composites, vol. 104, no. 1. CreateSpace, 2014.

[2] M. A. Muflikhun, T. Yokozeki, and T. Aoki, "The strain performance of thin CFRP-SPCC hybrid laminates for automobile structures," Compos. Struct., vol. 220, no. March, pp. 11-18, 2019.

[3] S. Das and T. Yokozeki, "Polyaniline-based multifunctional glass fiber reinforced conductive composite for strain monitoring," Polym. Test., vol. 87, no. April, p. 106547, 2020.

[4] S. Das, V. Kumar, and T. Yokozeki, "Strain sensing behavior of multifunctional polyaniline-based thermoset polymer under static loading conditions," Polym. Test., vol. 77, no. February, p. 105916, 2019.

[5] L. Guadagno et al., "Development of self-healing multifunctional materials," Compos. Part B Eng., vol. 128, pp. 30-38, 2017.

[6] M. Arena, L. Vertuccio, G. Barra, M. Viscardi, and L. Guadagno, "Damping assessment of new multifunctional epoxy resin for aerospace structures," Mater. Today Proc., no. xxxx, 2020.

[7] N. Forintos and T. Czigany, "Multifunctional application of carbon fiber reinforced polymer composites: Electrical properties of the reinforcing carbon fibers - A short review," Compos. Part B Eng., vol. 162, no. August 2018, pp. 331-343, 2019.

[8] N. Saba, M. Jawaid, M. T. H. Sultan, and O. Alothman, Hybrid multifunctional composites-recent applications. Elsevier Ltd, 2017.

[9] A. Al-Lami, P. Hilmer, and M. Sinapius, "Eco-efficiency assessment of manufacturing carbon fiber reinforced polymers (CFRP) in aerospace industry," Aerosp. Sci. Technol., vol. 79, pp. 669-678, 2018.

[10] Y. Kakichi et al., "Development of recyclable carbon fiber-reinforced plastics (CFRPs) with controlled degradability and stability using acetal linkage-containing epoxy resins," Polym. J., vol. 49, no. 12, pp. 851-859, 2017.

[11] I. I. Zulkepli, H. Mokhtar, Y. Aminanda, M. S. I. Shaik Dawood, and M. S. M. Rehan, "Review of Manufacturing Process for Good Quality of Composite Assessment,” IOP Conf. Ser. Mater. Sci. Eng., vol. 488, no. $1,2019$.

[12] Z. Zhang et al., "Bistable morphing composite structures: A review," Thin-Walled Struct., vol. 142, no. March, pp. 74-97, 2019.

[13] D. G. do. Santos, R. J. C. Carbas, E. A. S. Marques, and L. F. M. da Silva, "Reinforcement of CFRP joints with fibre metal laminates and additional adhesive layers," Compos. Part B Eng., vol. 165, no. November 2018, pp. 386-396, 2019.

[14] A. Masouras, D. Giannopoulos, B. Hasa, A. Katsaounis, and V. Kostopoulos, "Hybrid graphene nanoplatelet/manganese oxide electrodes for solid-state supercapacitors and application to carbon fiber composite multifunctional materials," J. Energy Storage, vol. 23, no. April, pp. 515-525, 2019.

[15] A. T. T. Nguyen, C. K. Amarasinghe, M. Brandt, S. Feih, and A. C. Orifici, "Loading, support and geometry effects for pin-reinforced hybrid metal-composite joints," Compos. Part A Appl. Sci. Manuf., vol. 98, pp. 192206, 2017.

[16] A. Gbaguidi, S. Namilae, and D. Kim, "Monte Carlo Model for Piezoresistivity of Hybrid Nanocomposites," J. Eng. Mater. Technol., vol. 140, no. 1, p. 011007, 2017. 
[17] K. Zhang, D. Shi, W. Wang, and Q. Wang, "Mechanical characterization of hybrid lattice-to-steel joint with pyramidal CFRP truss for marine application," Compos. Struct., vol. 160, pp. 1198-1204, 2017.

[18] M. A. Muflikhun, R. Higuchi, T. Yokozeki, and T. Aoki, "Failure mode analysis of CFRP-SPCC hybrid thin laminates under axial loading for structural applications : Experimental research on strain performance," Compos. Part B Eng., vol. 172, no. 2, pp. 262-270, 2019.

[19] M. Barletta, G. Rubino, V. Tagliaferri, F. Trovalusci, and S. Vesco, "Wood-reinforced polyphthalamide resins: Multifunctional composite coating for metal substrates," Int. J. Polym. Sci., vol. 2014, 2014.

[20] Y. Zhou, A. M. LaChance, A. T. Smith, H. Cheng, Q. Liu, and L. Sun, "Strategic Design of Clay-Based Multifunctional Materials: From Natural Minerals to Nanostructured Membranes," Adv. Funct. Mater., vol. 29, no. 16 , pp. 1-18, 2019.

[21] D. L. Gin and R. D. Noble, "Designing the next generation of chemical separation membranes," Science (80-. )., vol. 332, no. 6030, pp. 674-676, 2011.

[22] P. Podsiadlo et al., "Ultrastrong and stiff layered polymer nanocomposites," Science (80-. )., vol. 318, no. 5847, pp. 80-83, 2007.

[23] J. Zhao et al., "Biomimetic and bioinspired membranes: Preparation and application," Prog. Polym. Sci., vol. 39, no. 9, pp. 1668-1720, 2014.

[24] J. P. D. Ed, Green Composites: Materials Manufacturing and Engineering, vol. 8, no. 9. 2017.

[25] Inamuddin, Ed., Green Polymer Composites Technology. CRC press, 2016.

[26] H. Ohsaki and Y. Kokubu, "Global market and technology trends on coated glass for architectural, automotive and display applications," Thin Solid Films, vol. 351, no. 1-2, pp. 1-7, 1999.

[27] R. deRichter and S. Caillol, "Fighting global warming: The potential of photocatalysis against CO2, CH4, N2O, CFCs, tropospheric O3, BC and other major contributors to climate change," J. Photochem. Photobiol. C Photochem. Rev., vol. 12, no. 1, pp. 1-19, 2011.

[28] C. Le Quere et al., "The global carbon budget 1959 - 2011," Earth Syst. Sci. Data, vol. 5, no. December 2012, pp. 165-185, 2013.

[29] C. Le Quéré, R. Moriarty, R. M. Andrew, J. G. Canadell, S. Sitch, and J. I. Korsbakken, "Global Carbon Budget 2015,” Earth Syst. Sci. Data, vol. 7, pp. 349-396, 2015.

[30] H. M. N. Iqbal, G. Kyazze, T. Tron, and T. Keshavarz, "Laccase from Aspergillus niger: A novel tool to graft multifunctional materials of interests and their characterization," Saudi J. Biol. Sci., vol. 25, no. 3, pp. 545-550, 2018.

[31] J. Sheikh and M. D. Teli, "Bamboo Rayon-ZnO Nanoparticles Composite as Multifunctional Textile Materials," J. Text., vol. 2014, pp. 1-5, 2014.

[32] R. J. K. Wood, Multifunctional materials for tribological applications. CRC press, 2015.

[33] Z. Lin, M. Ye, and M. Wang, Eds., Multifunctional Photocatalytic Materials for Energy. Elsevier B.V, 2018.

[34] E. J. Siochi and J. S. Harrison, "Structural nanocomposites for aerospace applications," MRS Bull., vol. 40, no. 10, pp. 829-835, 2015.

[35] M. A. Muflikhun, R. Higuchi, T. Yokozeki, and T. Aoki, "Delamination behavior and energy release rate evaluation of CFRP/SPCC hybrid laminates under ENF test: Corrected with residual thermal stresses," Compos. Struct., 2020.

[36] M. A. Muflikhun, R. Higuchi, T. Yokozeki, and T. Aoki, "The evaluation of failure mode behavior of CFRP/Adhesive/SPCC hybrid thin laminates under axial and flexural loading for structural applications," Compos. Part B Eng., 2020.

[37] V. C. Raguin, "Revivals, Revivalists, and Architectural Stained Glass," J. Soc. Archit. Hist., vol. 49, no. 3, pp. 310-329, 1990.

[38] X. Zhang, Y. Chen, and J. Hu, "Recent advances in the development of aerospace materials," Prog. Aerosp. Sci., vol. 97, no. January, pp. 22-34, 2018.

[39] L. Zhu, N. Li, and P. R. N. Childs, "Light-weighting in aerospace component and system design," Propuls. Power Res., vol. 7, no. 2, pp. 103-119, 2018.

[40] P. R. Jagadish et al., "Cost effective thermoelectric composites from recycled carbon fibre: From waste to energy,” J. Clean. Prod., vol. 195, pp. 1015-1025, 2018.

[41] M. K. Hagnell, B. Langbeck, and M. Åkermo, "Cost efficiency, integration and assembly of a generic composite aeronautical wing box," Compos. Struct., vol. 152, pp. 1014-1023, 2016.

[42] J. Flynn, A. Amiri, and C. Ulven, "Hybridized carbon and flax fiber composites for tailored performance," Mater. Des., vol. 102, pp. 21-29, 2016.

[43] M. Megahed, R. M. Abo-bakr, and S. A. Mohamed, "Optimization of hybrid natural laminated composite beams for a minimum weight and cost design," Compos. Struct., vol. 239, no. December 2019, p. 111984, 2020.

[44] D. Nestler, M. Trautmann, S. Nendel, G. Wagner, and L. Kroll, "Innovative hybrid laminates of aluminium alloy foils and fibre-reinforced thermoplastic layers," Materwiss. Werksttech., vol. 47, no. 11, pp. 1121-1131, 2016.

[45] K. Y. Chan, B. Jia, H. Lin, N. Hameed, J. H. Lee, and K. T. Lau, "A critical review on multifunctional composites as structural capacitors for energy storage," Compos. Struct., vol. 188, no. November 2017, pp. 126142, 2018.

[46] D. W. Cho et al., "Fabrication and environmental applications of multifunctional mixed metal-biochar composites (MMBC) from red mud and lignin wastes," J. Hazard. Mater., vol. 374, no. September 2018, pp. 412-419, 2019. 
[47] K. H. Nam et al., "Sustainable production of reduced graphene oxide using elemental sulfur for multifunctional composites," Compos. Part B Eng., vol. 176, no. August, p. 107236, 2019.

[48] P. Rakesh, V. Diwakar, K. Venkatesh, and R. N. Savannananavar, "A Concise Report on properties of Hybrid Composites manufactured from glass and natural fibers," Mater. Today Proc., vol. 22, pp. 2008-2015, 2019.

[49] F. Chegdani, B. Takabi, M. El Mansori, B. L. Tai, and S. T. S. Bukkapatnam, "Effect of flax fiber orientation on machining behavior and surface finish of natural fiber reinforced polymer composites," J. Manuf. Process., vol. 54, no. March, pp. 337-346, 2020.

[50] M. shariff, M. Nagamadhu, M. Jaiprakash, K. Karthikeyan, and Kiran, "Effect of drilling process parameters on natural fiber reinforced basket epoxy composites using grey relational analysis," Mater. Today Proc., vol. 24, pp. 2255-2264, 2020.

[51] L. Kerni, S. Singh, A. Patnaik, and N. Kumar, "A review on natural fiber reinforced composites," Mater. Today Proc., no. xxxx, 2020.

[52] R. K. Malviya, R. K. Singh, R. Purohit, and R. Sinha, "Natural fibre reinforced composite materials: Environmentally better life cycle assessment - A case study," Mater. Today Proc., vol. 26, pp. 3157-3160, 2020.

[53] N. Mehmandost, M. L. Soriano, R. Lucena, N. Goudarzi, M. A. Chamjangali, and S. Cardenas, "Recycled polystyrene-cotton composites, giving a second life to plastic residues for environmental remediation," $J$. Environ. Chem. Eng., vol. 7, no. 5, p. 103424, 2019. 